\title{
Synthesis and Characterization Molecularly Imprinted Polymers for Analysis of Dimethylamylamine Using Acrylamide as Monomer Functional
}

\section{Sintesis dan Karakterisasi Molecularly Imprinted Polymers untuk Analisis Dimetilalamin Menggunakan Akrilamid sebagai Monomer Fungsional}

\author{
Saeful Amin ${ }^{1,2^{*}}$, Sophi Damayanti ${ }^{1}$, Slamet Ibrahim ${ }^{1}$ \\ ${ }^{1}$ Bandung Institute of Technology, Bandung, Indonesia \\ ${ }^{2}$ Program Study of Pharmacy, STIKes Bakti Tunas Husada, Tasikmalaya, Indonesia. \\ *E-mail: saeful_amin@stikes-bth.ac.id and sibrahim@fa.itb.ac.id
}

\begin{abstract}
A selective separation techniques with Molecularly Imprinted Polymer (MIP) for High-Performance Liquid Chromatography (HPLC) has been developed for the assay of Dimethylamylamine (DMAA) doping compounds. Molecular imprinted polymer (MIP) is a technique to produce a polymer having the cavity due to the disposal of the templates, in which the cavity serves to recognize the molecules of the same size, structure, chemical and physical properties. The selectivity and affinity of the templates itself will increase, while the concentration value is increasing. MIP is made by DMAA as template, acrylamide as functional monomer, ethylene glycol dimethacrylate (EGDMA) as cross linking, azobisisobutyronitrile (AIBN) as the initiator and chloroform as a porogen solvent; using bulk method. The aim of research are conduct the MIP for the DMAA compound analysis, then the formed MIP is characterized by using Fourier Transform Infra Red (FTIR) and Scanning Electron Microscopy (SEM) to find out the polymer complexes formed and the morphological form of the MIP. The MIP formed then was analyzed by using High-Performance Liquid Chromatography (HPLC) to know the amount of the DMAA, the adsorption capacity, and the adsorption condition found in the MIP. The result of analysis on the content of DMAA in the MIP by using UV-Vis Spectrophotometer is $1.957 \mathrm{mg}$. Scanning Electron Microscopy (SEM) shows that the MIP has irregular and rough morphological structure; while the NIP has irregular morphology structures and smooth surfaces shape.
\end{abstract}

Keywords: DMAA; Doping; MIP; SEM; FTIR

\begin{abstract}
Abstrak
Teknik pemisahan selektif dengan Molecularly Imprinted Polymer (MIP) menggunakan High-Performance Liquid Chromatography (HPLC) telah dikembangkan untuk pengujian senyawa doping Dimethylamylamine (DMAA). Molecular imprinted polymer (MIP) adalah teknik untuk menghasilkan polimer yang memiliki rongga karena pembuangan template, di mana rongga berfungsi untuk mengenali molekul dengan ukuran, struktur, kimia dan sifat fisik yang sama. Selektivitas dan afinitas template itu sendiri akan meningkat, sementara nilai konsentrasinya meningkat. MIP dibuat oleh DMAA sebagai template, akrilamida sebagai monomer fungsional, etilena glikol dimetakrilat (EGDMA) sebagai penghubung silang, azobisisobutyronitrile (AIBN) sebagai inisiator dan kloroform sebagai pelarut porogen; menggunakan metode massal. Tujuan penelitian adalah melakukan MIP untuk analisis senyawa DMAA, kemudian membentuk MIP dikarakterisasi menggunakan Fourier Transform Infra Red (FTIR) dan Scanning Electron Microscopy (SEM) untuk mengetahui kompleks polimer yang terbentuk dan bentuk morfologi dari MIP. MIP yang terbentuk kemudian dianalisis dengan menggunakan High-Performance Liquid Chromatography (HPLC) untuk mengetahui jumlah DMAA, kapasitas adsorpsi, dan kondisi adsorpsi yang ditemukan di MIP. Hasil analisis pada isi DMAA di MIP dengan menggunakan Spektrofotometer UV-Vis adalah 1,957 mg. Scanning Electron Microscopy (SEM) menunjukkan bahwa MIP memiliki struktur morfologi yang tidak teratur dan kasar; sedangkan NIP memiliki struktur morfologi yang tidak teratur dan bentuk permukaan yang halus.
\end{abstract}

Kata Kunci: DMAA; Doping; MIP; SEM; FTIR 


\section{INTRODUCTION}

Sport is an activity that can not be separated from human life and is an important factor in the maintenance of health. According to the United Nations Educational Scientific and Cultural Organization (UNESCO), sport is physical activity in the form of a game that contains a struggle against the elements of nature, others or themselves. Along with the times, sport is not only a means for the maintenance of human health but also a competition on behalf of a nation and country. ${ }^{1}$

Today, the value of sportsmanship in some areas of the sport is often stained by the use of doping consumed by athletes. Competition in increasingly fierce sport achievements has led some athletes to justify any ways to win. Some ambitious coaches try to improve the athlete performance in a variety of ways, such as harder exercise, taking advantage of technological advances, or even through a shortcut to prescribe doping for the sake of achievement and to enhance the performance of athletes. $^{2}$

According to Law No. 3 of 2005 on National Sports System, doping is the use of substance and / or prohibited method to increase performance in sports. Dimethylamylamine compounds (DMAA) is one of most widely used stimulants class of doping compounds. ${ }^{3}$

DMAA is also known as 1,3dimethylamylamine, methylhexaneamine and 2-amino-4-methylhexane. It was firstly named 'Forthane' and introduced by Eli Lilly \& Co. as a vasoconstrictor in the 1940s. After several decades, Forthane has been a trademark known as Geranamine and introduced to the world of sport as an ingredient in some pre-workout supplements. ${ }^{4}$

In 2009, the World Anti-Doping Agency (WADA) added DMAA to the list of banned substances in the class of nonspecific stimulants (S6) . ${ }^{5}$ Later in 2011 up to now, DMAA was moved into the class of specific stimulant (S6). ${ }^{6}$
DMAA can be found in the samples of supplements which usually consists of various materials, mainly protein. Various methods for the analysis of DMAA compounds had been developed, one of which was carried out by $\mathrm{Li}$ and Chen (2012) using High-Performance Liquid Chromatography (HPLC) with Mass Spectrometer (MS) detector. ${ }^{7}$ However, to perform the analysis, good separation technique is required because in spite of rapid development in analysis technology, the instrument still can not handle the matrix directly. Therefore, many separation method is developed with good selectivity towards the analyte.

One of the many separation technique developed nowadays is Molecularly Imprinted Polymer Imprinted Polymer (MIP). MIP is a new technology that imitate the enzyme ability to capture the substrate selectively with the creation of molecular recognition sites selectively by printing these molecules in the polymer material. ${ }^{8}$ The advantage of MIP are high selectivity and good affinity toward the analyte. ${ }^{9}$

The aim of the present study is to develop separation techniques of DMAA compounds. The formed MIP will be characterized by using Fourier Transform Infra Red (FTIR) and Scanning Electron Microscopy (SEM) to determine the formed polymer complex and the morphological form of MIP. Furthermore, the formed MIP will be analyzed by using High-Performance Liquid Chromatography (HPLC) to find out the amount of DMAA, adsorption capacity, and desorption available on MIP.

\section{METHODS}

The tools used in this study was a micro pipette, lidded vial, sonicator, Metler Toledo analytical balance, spatula, funnel, cuvette, UV-Vis Spectrophotometer Genesys 10S UV-Vis, Fourier Transform Infra-Red (FTIR Prestige 21 Shimadzu), Scanning Electron Microscope with Energy Dispersive X-ray System (JEOL 
JSM-6360LA) and glassware commonly used in pharmaceutical laboratory analysis.

Materials used in this research was Dimethylamylamine (DMAA) (SigmaAldrich), acrylamide from PT. Merck, Ethylene glycol dimethacrylate (EGDMA) (Sigma-Aldrich), azobisisobutyronitrile (AIBN) (Sigma-Aldrich), chloroform p.a (Merck) and methanol p.a (Merck)

\section{Synthesize of Molecular Imprinted Polymer (MIP)}

MIP fabrication performed using bulk method by which the template molecules, functional monomer, crosslinking and initiator were dissolved in a porogen solvent in a container and then the reaction was initiated by heating. Comparison ratio between template molecule: functional monomer: crosslinking was 1:4:20 (in mol). DMAA dissolved in chloroform in a lidded vial, then sonicated for 15 minutes to ensure that DMAA had been dissolved. Acrylamide added to the vial and sonicated for 30 minutes for introduction of the template molecule to the monomer and removed oxygen. EGDMA and AIBN added to the vial, sonicated for 5 minutes, the vial was covered tightly and sealed with aluminum foil and plastic wrap. The mixture in the vial was initiated with heating for 24 hours. For comparison, Non-imprinted polymer (NIP) was synthesized with the same composition and method of the MIP, but without the addition of DMAA as the print molecular.

\section{Release Template Molecule}

The release of template molecules was performed by mixing MIP and NIP with 5 $\mathrm{mL}$ of chloroform. Then it was shaken and sonicated for 5 minutes.

\section{Analysis DMAA use UV-Vis spectrophotometer}

DMAA was taken for $25 \mu \mathrm{L}$ using a micro pipette to be added to $25 \mathrm{~mL}$ volumetric flask and dissolved in chloroform to the mark of limit.

\section{Scanning Wavelength of DMAA}

DMAA dissolved in chloroform and its maximum wavelength was measured at 200-800 nm using a UV-Vis spectrophotometer with chloroform blank.

\section{Standard Calibration Curve of DMAA}

DMAA main solution 1000 ppm took at 1.0, 1.5, 2.0, 2.5, 3.0, and $3.5 \mathrm{~mL}$ for the creation of DMAA dilution series in chloroform at a concentration of 200, 300, $400,500,600$ and $700 \mathrm{ppm}$. Then a calibration curve created between concentration (ppm) and absorbance (A). The line equation was determined by linear regression method.

\section{Determination of DMAA From MIP}

Template molecule release procedure conducted, then the extraction result was filtered by using filter paper. The filtrate absorbance was measured at the DMAA maximum wavelength and calculation of the levels of DMAA in the MIP. The same treatment was performed to the NIP for comparative purposes.

\section{MIP Characterization \\ Scanning Electron Microscopy (SEM)}

MIP and NIP were characterized by SEM by ways of a sample placed on the specimen holder then was cleaned with a hand blower. Samples in the specimen holder were given a thin layer (coating) with gold-palladium and then were inserted into specimen chamber and analyzed at magnification of 500x and 25000x.

\section{Fourier Transform Infra Red (FTIR)}

DMAA, MIP before the extraction, MIP after extraction, NIP before extraction and NIP after extraction were characterized by FTIR. Sample preparation was performed using potassium bromide (KBr) pellet method by which sample in form of powder was mixed with $\mathrm{KBr}$ by a ratio of 1: 100 and crushed until homogeneous, afterward put it in a mold disc, then compressed it at a pressure of 20 
psi using a hydraulic press. The disc was mounted on the holder then the spectrum was measured using FTIR.

\section{RESULT AND DISCUSSION}

\section{Synthesis of MIP and NIP acrylamide}

MIP synthesis performed by trial and error steps and based on non-covalent interactions using bulk method. Template, functional monomer, crosslinking and reaction initiator were incorporated into a container with porogen solvents and then were incubated at a high temperature to initiate polymerization. ${ }^{10}$ Non-covalent interactions were more commonly used than covalent interaction because it did not require a synthetic step for the formation of complex polymers; interactions between monomer and template was easily occurred; template release was easier to do and variety of functional groups that can be recognized on the binding site in MIP was more numerous. ${ }^{11}$

This study used DMAA a template which was a compound to be analyzed. Acrylamide monomer used as a functional monomer providing functional group that was responsible for interacting with the template. Acrylamide can form hydrogen bonds between the carbonyl group of acrylamide and a proton donor of the template. ${ }^{12}$ Previous studies mentioned that acrylamide was a suitable monomer for the synthesis of MIP as good polymer was obtained in terms of the amount of polymer formed as well as the physical quality of the polymer (texture, color, homogeneity). Stronger interaction between the template and the monomer at the time of printing has produced MIP with better bonding capacity and selectivity. Amide group in acrylamide could form stronger hydrogen bonds with the template than the carboxyl group. ${ }^{13}$

Crosslinking used etilenglicol dimetacrilat (EGDMA) with molecular formula of $\mathrm{C}_{10} \mathrm{H}_{14} \mathrm{O}_{4}$ (Mr 198.22; $\rho=1.051$ $\mathrm{gr} / \mathrm{mL})$. EGDMA was one of most often used crosslinker in the synthesis of MIP because it could produce a polymer which has good thermal and mechanical stability; could form a stable polymer; have good porosity and easily polymerized. ${ }^{14}$

Reaction initiator used azobis isobutyronitrile (AIBN). AIBN could form free radicals by heating at low temperature by $60-70^{\circ} \mathrm{C}$ and a suitable initiator for use in the synthesis of MIP with the bulk method. ${ }^{10}$ Porogen solvent used chloroform because in this study, the MIP synthesis was based on non-covalent interactions that were hydrogen bonds. Solvent with a low polarity such as chloroform could enhance complex formation, eliminate other nonspecific interactions and form a better atmosphere for the occurrence of hydrogen bonds .12

Synthesis optimization conducted with literature study to find the ideal composition of the comparison among the templates: a functional monomer: crosslinking. Based on the literature study, the ratio of template: functional monomer: crosslinking for MIP synthesis in general was 1:4:20 (in mol) as sufficient to produce a stable complex interaction. Interactions between the template and the monomer were an equilibrium process, so as to shift the equilibrium towards the formation of template-monomer complex. The amount of monomer was added in excess. However, an excess amount of monomer could also cause the formation of polymers with non-specific binding sites. ${ }^{15}$

MIP made with the target synthesis product as much as 1 gram for one synthesis, DMAA stock was taken as much as $4.32 \mathrm{ml}$ pipette into the lidded vial, then $65.15 \mathrm{mg}$ of acrylamide was added into the vial and sonicated until the acrylamide get dissolved. Sonication served for the template introduction to the functional monomer. EGDMA as much as $865.14 \mu \mathrm{L}$ and AIBN $304.00 \mu \mathrm{L}$ were added to the vial and sonicated to remove oxygen. Vials were closed and sealed with aluminum foil and plastic wrap and were initiated at a temperature of $60-70^{\circ} \mathrm{C}$ for 24 hours with observations every 2 hours. NIP was synthesized by the same number and 
conditions of MIP synthesis but without the addition of DMAA as a template. NIP synthesis was used as a benchmark to determine the ability of MIP in interacting with DMAA and as a comparison in the release of MIP from DMAA.

Organoleptically, synthesis results showed that MIP and NIP have solid form. MIP was yellowish white while the NIP was white (Figure 1).

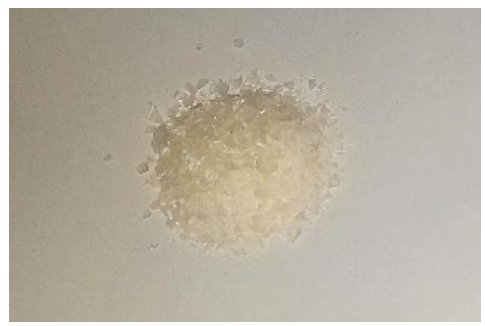

(a)

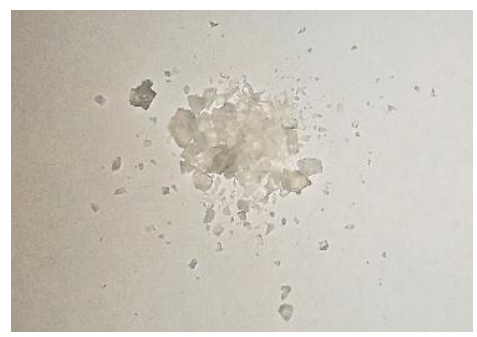

(b)

Figure 1. Cristal form, (a) MIP and

(b) NIP

\section{Analysis with UV-Vis Spectro photometer Determination of DMAA Wave-length \\ Analysis using UV-Vis}

spectrophotometer began with determining maximum wavelength of DMAA. DMAA was dissolved in chloroform then its maximum wavelength was measured in the range of 200-800 $\mathrm{nm}$. The maximum wavelength of DMAA in chloroform was obtained at $313 \mathrm{~nm}$ (Figure 2).

Measurement of the maximum wavelength was conducted because with the maximum wavelength, the absorbance curve shape was flat and in that condition, Lambert-Beer law was fulfilled and errors in measurement would be very small. ${ }^{16}$ DMAA maximum wavelength measurements (Figure 2) resulted in two absorption peaks that of $246 \mathrm{~nm}$ and $313 \mathrm{~nm}$. Solvent used in the measurement of the DMAA maximum wavelength was chloroform. Chloroform is an organic solvent that has a minimum transparency limit in ultraviolet area at a wavelength of $250 \mathrm{~nm},{ }^{17}$ so the $246 \mathrm{~nm}$ absorption peak was assumed to be the maximum wavelength of chloroform and $313 \mathrm{~nm}$ was a maximum wavelength of DMAA.

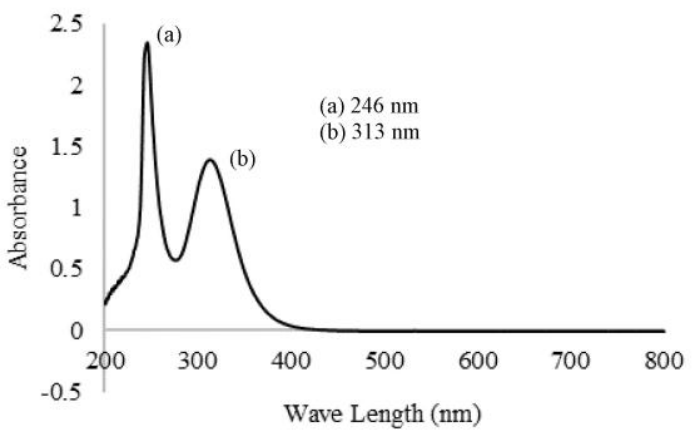

Figure 2 Graphs on the measurement of DMAA maximum wavelength in chloroform. (a) $246 \mathrm{~nm}$ (b) $313 \mathrm{~nm}$

\section{DMAA Calibration Curve}

A calibration curve was a line obtained from the points which expressed a concentration against absorbance absorbed after linear regression analysis was performed. ${ }^{18}$ The maximum of calibration curve was performed at the DMAA maximum wavelength $313 \mathrm{~nm}$. The main solution made is $1000 \mathrm{ppm}$, then the dilution series is created with a concentration of $700,600,500,400,300$ and $200 \mathrm{ppm}$. The results of DMAA calibration curve in chloroform (Figure 3 ).

The results of calibration curve in Figure 3 resulted in a regression equation $\mathrm{y}=0.0008 \mathrm{x}+0.1399$ and the regression coefficients $\left(\mathrm{R}^{2}\right)$ of 0.9972 with a correlation coefficient (r) of 0.999 . The regression coefficient $\left(\mathrm{R}^{2}\right)$ of 0.998 stated that there was a close correlation and good linearity between DMAA concentration in chloroform and its absorbance. This was because the value range of $\mathrm{R}^{2}$ was within interval of $0.9<\mathrm{R}^{2}<1$. $\mathrm{r}$ value for 0,999 stated that all points lied on a straight line 
with positive slope because the value was at $-1 \leq \mathrm{r} \leq 1$.

Absorbance readable at the spectrophotometer was in the range between 0.2 to 0.8 because they were at a minimum range of error or error analysis can be accepted with an error in $\mathrm{T}$ reading which was 0.005 , or $0.5 \%$ (photometric error).

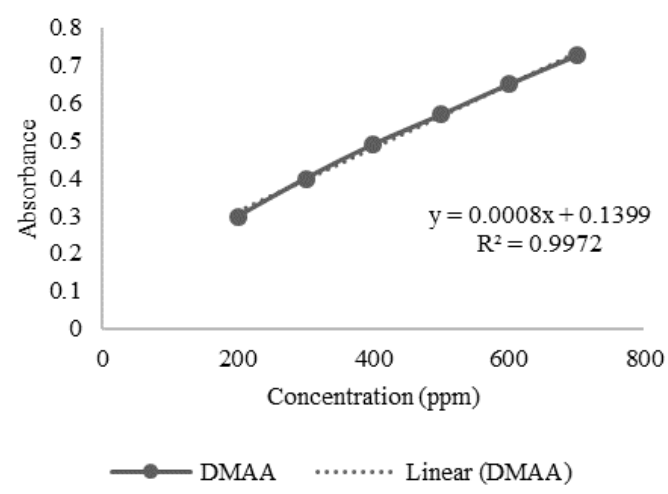

Figure 3. DMAA Calibration curve

\section{DMAA Determination in MIP Using UV-Vis Spectrophotometry}

Determination of DMAA in MIP was performed by weighing MIP as much as 50 $\mathrm{mg}$. The MIP was mixed with as much as 5 $\mathrm{mL}$ chloroform and stirred, then it was sonicated for 5 minutes to accelerate the extraction process of DMAA from MIP. The mixture was filtered and the filtrate was measured for its absorbance at $313 \mathrm{~nm}$ wavelength. The same treatment was performed on NIP which served as a comparison. Data showed that the DMAA absorbance in $50 \mathrm{mg}$ samples of MIP was 0.453; containing DMAA $1.956875 \mathrm{mg}$, whereas the absorbance of NIP sample was 0.029; and it did not contain DMAA.

The results show MIP contained DMAA while the NIP did not contain DMAA as proven by the results of MIP and NIP wavelengths measurements (Figure 4). The MIP (blue) produced a peak at wavelengths of $313 \mathrm{~nm}$, while the NIP did not produce a peak at a wavelength of $313 \mathrm{~nm}$.

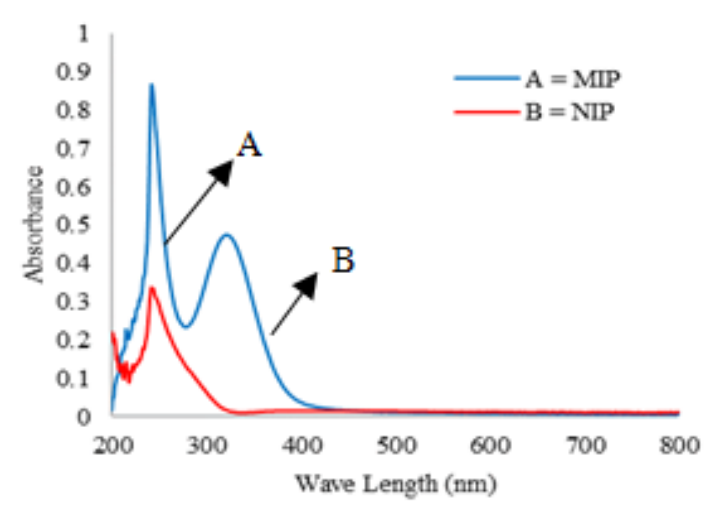

Figure 4. Overlay of MIP and NIP extraction result

\section{Characterization MIP/NIP Using SEM}

Scanning Electron Microscopy (SEM) is a type of microscope that uses electrons instead of light to see objects with high resolution; SEM analysis was helpful to recognize microstructures (including porosity and cracks form) of solid things. ${ }^{19}$ SEM analysis was conducted on MIP and NIP with each magnification of 500x and 25000x (Figures 5).

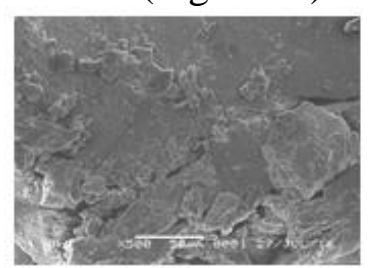

(a)

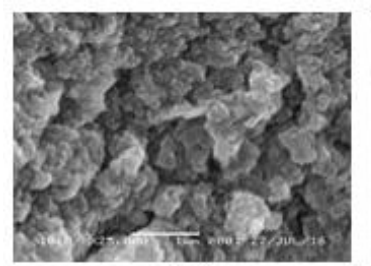

(c)

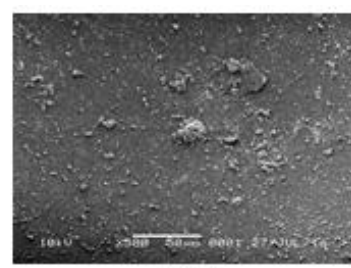

(b)

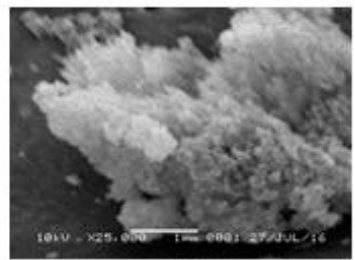

(d)
Figure 5. SEM Result at magnification of 500x on (a) MIP, (b) NIP and magnification of 25000x on (c) MIP, (d) NIP

SEM analysis shows morphological differences between MIP and NIP. MIP had an irregular, rough morphological structure (like micro particles with a small cavity), while the NIP was regular morphological structure with smooth surface. Regular NIP structure indicated that there was no specific binding sites formed by the template, while the cavity 
formed in the MIP was due to template molecule printed. ${ }^{20}$

\section{Characterization MIP/NIP Using FTIR}

Analysis by FTIR spectroscopy was based on the characteristics of the functional groups contained in the MIP and NIP sample. FTIR spectral data of each sample were obtained from the results of sample scanning with the FTIR instrument at IR region with wave number of 4400$400 \mathrm{~cm}^{-1}$. From the test of FTIR spectroscopy with the DMAA standard, IR spectrum was obtained (Figure 6).

FTIR spectrum of DMAA standard (Figure 6) showed some of different peaks in the absorption area of $3408.22 \mathrm{~cm}^{-1}$; $2962.66 \mathrm{~cm}^{-1} ; 2922.16 \mathrm{~cm}^{-1} ; 2875.86 \mathrm{~cm}^{-1}$; $1573.91 \mathrm{~cm}^{-1} ; \quad 1462.04 \mathrm{~cm}^{-1}$ and $1377.17 \mathrm{~cm}^{-1}$. Absorption appeared in the area of $3500-3400 \mathrm{~cm}^{-1}$ was an amine group $\left(\mathrm{NH}_{2}\right)$ stretching, absorption at wave number of 2962-2872 $\mathrm{cm}^{-1}$ was a methyl group $\left(\mathrm{CH}_{3}\right)$ stretching, absorption at wave number of $1650-1560 \mathrm{~cm}^{-1}$ was $\mathrm{NH}$ bending, absorption at wave number of 1470-1430 $\mathrm{cm}^{-1}$ was a $\mathrm{CH}_{2}$ bending, and absorption at wave number of 1390-1370 $\mathrm{cm}^{-1}$ was a methyl group $\left(\mathrm{CH}_{3}\right)$ bending.

After FTIR spectrum of DMAA standard was recognized, characterization was performed using FTIR toward samples of MIP and NIP (Figure 7). MIP and NIP Spectrum showed that the polymer had been formed as indicated by the absorption appeared at wave number of $1635.64 \mathrm{~cm}^{-1}$. Absorption at wave number of 1640$1635 \mathrm{~cm}^{-1}$ was an acrylate group. Acrylate group was derived from acrylamide used as a functional monomer of constituent polymers.

FTIR spectrum of MIP and NIP produced did not have significant differences in the spectrum. Some of functional groups of DMAA were similar to the functional groups contained in the polymer framework of MIP and NIP, namely on the wave number of 3500$3400 \mathrm{~cm}^{-1}$ region, the wave number 2962 $2872 \mathrm{~cm}^{-1}$, the wave number 1470-
$1430 \mathrm{~cm}^{-1}$, and the wave number 1390 $1370 \mathrm{~cm}^{-1}$. However, at the wave number of $1650-1560 \mathrm{~cm}^{-1}$ which was $\mathrm{NH}$ bending of DMAA was not visible on the FTIR spectrum of MIP. It was caused by not homogeneous DMAA contained in the MIP.

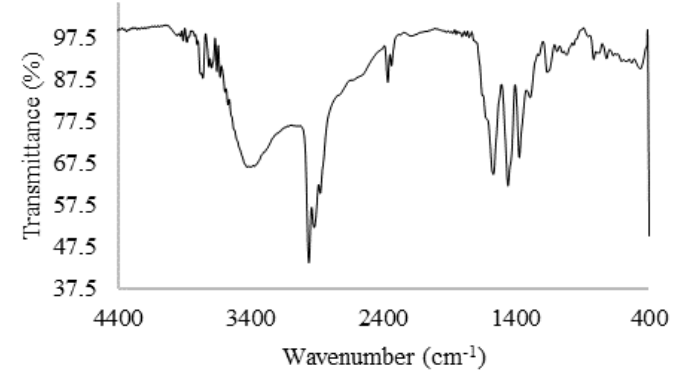

\section{Figure 6. FTIR Spectrum of DMAA standard}

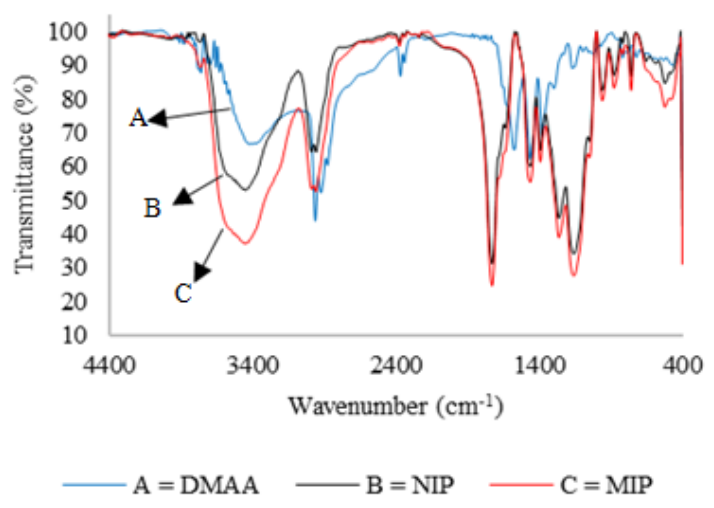

Figure 7. FTIR spectrum Overlay of MIP and NIP

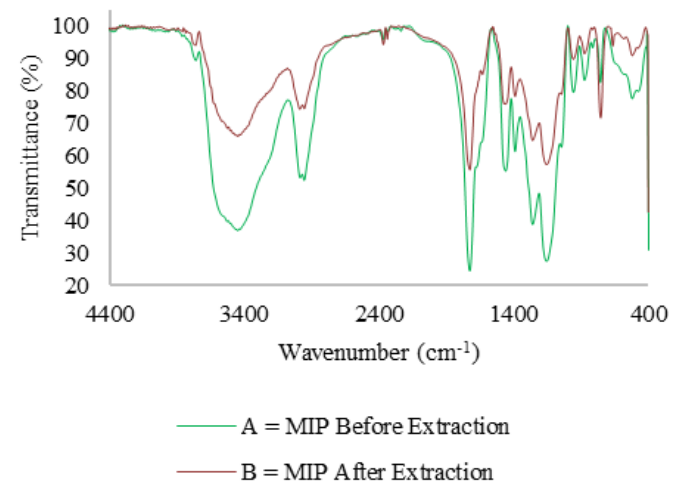

Figure 8. Overlay on FTIR spectrum of MIP before and after extraction 
Characterization using FTIR was performed as well on MIP and NIP that had been extracted. The FTIR spectrum of MIP after extraction showed the same as FTIR spectrum of MIP before the extraction (Figure 8).

The same thing was shown by FTIR spectrum of NIP extracted with FTIR spectrum of NIP before extracted (Figure 9). No changes of functional groups contained in MIP and NIP spectrum either before and after extraction showed that DMAA was not detected in the MIP. It was caused by nonhomogeneous DMAA contained in the MIP.

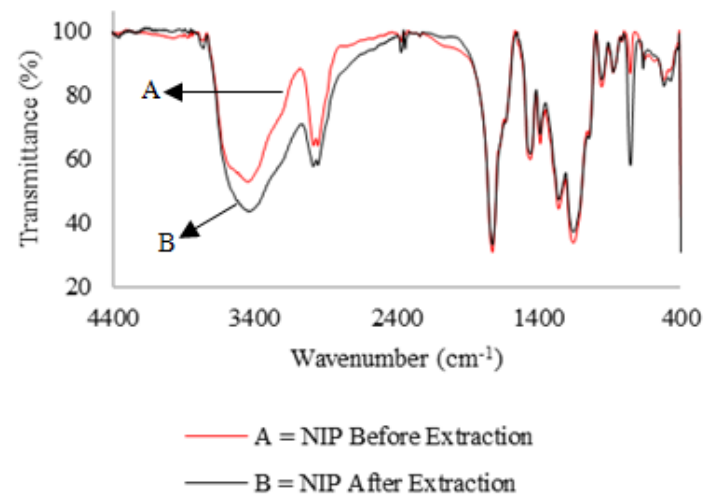

Figure 9. Overlay on FTIR spectrum of NIP before and after extraction

\section{CONCLUSION}

The making of Molecular imprinted polymers (MIP) was performed using bulk method. Materials used were DMAA as a template; acrylamide as a functional monomer; EGDMA as crosslinking; AIBN as initiator and chloroform as a porogen solvent with a comparison between the template: functional monomer: crosslinking (1:4:20) in moles.

Analysis with UV-Vis spectrophotometry showed that DMAA content extracted from MIP was $1.96 \mathrm{mg}$. Characterization by SEM showed morphological differences between MIP and NIP. Characterization using FTIR showed no significant differences between functional groups of MIP and NIP either before or after extraction because DMAA was not homogeneous in the MIP.

\section{ACKNOWLEDGMENT}

This research was financially supported by Research and Innovation Scientific Group Grant of the Bandung Institute of Technology 2017.

\section{REFERENCES}

1. Utomo DA. Upaya pencegahan penggunaan doping pada atlet cabang olahraga atletik di daerah istimewa Yogyakarta [Skripsi]. Yogyakarta: Fakultas Ilmu Keolahragaan Universitas Negeri Yogyakarta; 2014.

2. Madlizzari, D. Hubungan antara tingkat pengetahuan tentang jenis doping dan bahayanya dengan perilaku pemakaian doping pada atlet UKM pencak silat UPI Bandung [Skripsi]. Bandung: Universitas Pendidikan Indonesia; 2014.

3. WADA. Anti-doping testing figures report. http://www.wada-ama.org. 2015.

4. Zhang Y, Woods RM, Breitbach ZS, Daniel WA. 1,3-dimethylamylamine (DMAA) in supplements and geranium products: Natural or synthetic?. Drug Test and Analysis. 2012 Dec;4(12):986-90. doi: $10.1002 /$ dta. 1368 .

5. WADA. The 2010 Prohibited list international standard, the world antidoping agency code. http://www.wadaama.org. 2010.

6. WADA. The 2016 Prohibited list international standard, the world antidoping agency code. http://www.wadaama.org. 2016.

7. Li JS, Chen M, Li ZC. Identification and quantification of dimethylamylamine in geranium by liquid chromatography tandem mass spectrometry. Analytical Chemistry Insights. 2012;7:47-58. doi: 10.4137/ACI.S9969.

8. Sellergen J, Allender CJ. Molecularly imprinted polymers: A bridge to advanced drug delivery. Advanced Drug Delivery Reviews. 2005 Dec 6;57(12):1733-41.

9. Vasapollo G, Sole RD, Mergola L, Lazzoi MR, Scardino A, Scorrano S, et.al. Molecularly imprinted polymers: Present and future prospective. International Journal of Molecular Science. 2011;12(9):5908-5945. doi: 10.3390/ijms12095908. 
10. Lorenzo CA, Concheiro A. Handbook of molecularly imprinted polymers. United Kingdom: Smithers Rapra Technology. 2013.

11. Spivak DA. Optimization, evaluation, and characterization of molecularly imprinted polymers. Advanced Drug Delivery Reviews. 2005 Dec 6;57(12):1779-94. DOI: 10.1016/j.addr.2005.07.012.

12. Kartasasmita RE, Hasanah AN, Ibrahim S. Synthesis of selective molecularly imprinted polymer for solid-phase extraction of glipizide by using a pseudotemplate. Journal of Chemical \& Pharmaceutical Research. 2013;5(10):351-355.

13. Nguyen TH, Ansell RJ. Nisopropylacrylamide as a functional monomer for noncovalent molecular imprinting. Journal of Molecular Recognition. 2011; 25(1):1-10. doi: 10.1002/jmr.1163.

14. Stuti JSPR, Nigam I. Synthesis and characterization of crosslinkable copolymers of MMA with diacrylate/ dimethacrylate. Malaysian Polymer Journal. 2012;7(1): 34-41.
15. Windyasari I. Poli (Metil Metakrilat co Etilen Glikol Dimetakrilat) sebagai Kafein-Molecularly Imprinted Polymers (MIPs): Sintesis dan Karakterisasi [Tesis]. Bandung: Program Studi Magister Kimia Institut Teknologi Bandung; 2014.

16. Gandjar IG, Rohman A. Analisis obat secara spektroskopi dan kromatografi. Yogyakarta: Pustaka Pelajar; 2012.

17. Day RA, Underwood AL. Analisis kimia kuantitatif, edisi keenam. Jakarta: Erlangga; 2002.

18. Harisman FR, Sugiarso D. Pengaruh waktu penggilingan terhadap kadar zat besi dalam ampas sari kedelai menggunakan spektrofotometer UV-Vis. Jurnal Sains dan Seni Pomits. 2014;3(2):5-8

19. Gunawan B, Azhari CD. Karakterisasi spektrofotometri IR dan scanning electron microscopy (SEM) sensor gas dari bahan polimer poly ethelyn glycol (PEG). Jurnal Sains dan Teknologi. 2010;3(2):1-17.

20. Gonzalez GP, Hernando PF, Alegria JSD. A morphological study of molecularly imprinted polymers using the scanning electron microscope. Analytica Chimica Acta. 2005; 557 (1-2):179-83. 